УДК $581.2+581.522 .4$

Т. І. Юсипіва ${ }^{1}$, А. О. Задесенець ${ }^{2}$, Д. К. Злосчастьсва ${ }^{2}$

${ }^{1}$ Дніпровський національний університет імені Олеся Гончара

${ }^{2}$ Фінансово-економічний лічей Дніпровської міської ради

\title{
ВПЛИВ ТЕХНОГЕННИХ УМОВ ЗРОСТАННЯ НА ЗМІНИ МОРФОМЕТРИЧНИХ ПОКАЗНИКІВ ОДНОРІЧНОГО ПАГОНА ЯЛИНИ КОЛЮЧОЇ
}

Вивчено дію викидів Придніпровської ТЕС (м. Дніпро) на морфометричні показники однорічного пагона Picea pungens Engelm (f. viridis Regel.). Виявлено, що внаслідок хронічного впливу на рослини фітотоксикантів змінюсться інтенсивність росту пагонів і асиміляційного апарату. Запропоновано чутливі тест-параметри (величина річного приросту пагонів, довжина і маса хвоїнки) для фітоіндикації стану рослин ялини колючої в техногенних умовах зростання.

Ключові слова: однорічні пагони, біометричні показники, техногенне забруднення, Picea pungens Engelm.

\author{
Т. И. Юсыпива ${ }^{1}$, А. А. Задесенец ${ }^{2}$, Д. К. Злосчастьева ${ }^{2}$ \\ ${ }^{1}$ Днепровский начиональный университет имени Олеся Гончара \\ 2 Финансово-экономический лицей Днепровского городского совета

\section{ВЛИЯНИЕ ТЕХНОГЕННЫХ УСЛОВИЙ ПРОИЗРАСТАНИЯ НА ИЗМЕНЕНИЯ МОРФОМЕТРИЧЕСКИХ ПОКАЗАТЕЛЕЙ ОДНОЛЕТНЕГО ПОБЕГА ЕЛИ КОЛЮЧЕЙ}

Изучено действие выбросов Приднепровской ТЭС (г. Днепр) на морфометрические показатели однолетнего побега Picea pungens Engelm (f. viridis Regel.). Показано, что вследствие хронического влияния на растения фитотоксикантов изменяется интенсивность роста побегов и ассимиляционного аппарата. Предложены чувствительные тест-параметры (величина годичного прироста побегов, длина и масса хвоинки) для фитоиндикации состояния растений ели колючей в техногенных условиях произрастания.

Ключевые слова: однолетние побеги, биометрические показатели, техногенное загрязнение, Picea pungens Engelm.

\author{
T. Iusypiva ${ }^{1}$, A. Zadesenets $^{2}$, D. Zloschastyeva ${ }^{2}$ \\ ${ }^{1}$ Oles' Honchar Dnipro National University \\ 2 Financial and Economic Lyceum of Dnipro City Council
}

\section{INFLUENCE OF TECHNOGENIC GROWTH CONDITIONS TO CHANGES IN MORPHOMETRIC PARAMETERS OF ANNUAL SHOOTS OF BLUE SPRUCE}

The paper examined the effect of emissions caused by Prydniprovska TPP (the city of Dnipro) on morphometric parameters of annual shoots of Picea pungens Engelm $(f$. viridis Regel.). Material selection was completed in September 2016 in artificial forest stands. The monitoring point is located on the territory adjacent to Prydniprovska TPP, which is the biggest polluter of the city with its major pollutants as $\mathrm{SO}_{2}, \mathrm{NO}_{2}$, solid impurities, $\mathrm{CO}$ ). The relatively clean reference area is located in the Botanical garden of Oles' Honchar Dnipro National University, where the concentrations of pollutants do not exceed the maximum permitted values according to the City Sanitation Committee report. The research object was the species of Picea pungens Engelm ( $f$. Viridis Regel.).

It was ascertained, that under the constant influence of phytotoxic pollutants on the plants the intensity of shoot growth and assimilation system change, which becomes evi-

(C) Т. І. Юсипіва, А. О. Задесенець, Д. К. Злосчастьєва, 2017 
dent as reduction of the length of the lateral shoots, length and weight of needles, and an increase of the shoot needle-packing factor. Needle growth factor of blue spruce is not informative feature of the plant state in the industrial area, because it does not change when exposed to pollutants. The study suggests sensitive test parameters such as size of annual shoot growth, length and weight of needles to conduct phytoindication of the state of the blue spruce plants in anthropogenic conditions of growth.

Keywords: annual shoots, biometrics, technogenic pollution, Picea pungens Engelm.

Техногенне навантаження на довкілля - один із самих значущих екологічних факторів, що спричиняють деградацію штучних лісових фітоценозів Степового Придніпров'я [5]. Емісії промислових підприємств і викиди автотранспорту ушкоджують асиміляційний апарат деревних порід, знижуючи їх приріст, продуктивність окремих видів рослин і фітоценозу в цілому [2].

Дослідження змін морфометричних показників рослин дає можливість не лише оцінити їх пошкодження, але й прогнозувати стійкість насаджень до певних техногенних умов [1]. Аналіз літературних джерел свідчить про досить велику кількість наукових даних з проблеми вивчення впливу промислового забруднення на морфометричні показники асиміляційного апарату хвойних рослин, особливо в умовах Росії [10-12]. Однак в умовах Степової зони України це питання залишається вельми актуальним: роботи, що зрідка зустрічаються в літературі, головним чином, вивчали дії фітотоксикантів на біометричні характеристики пагонів представників родів Pinus L., Juniperus L. та ін. [3; 8; 9]. Наслідки антропогенного тиску на ріст рослин роду Picea A. Dietr. практично не вивчено. Зважаючи на це, мета роботи - проаналізувати зміни морфометричних показників однорічного пагона Picea pungens Engelm. в умовах техногенезу.

Об'єкти та методи досліджень. Об'єкт дослідження - інтродуцент ялина колюча Picea pungens Engelm. (f. viridis Regel.) - один із найпоширеніших в Україні представників родини Соснові (Pinaceae), роду Ялина, або Смерека (Picea A. Dietr.). Ялина колюча виконує в зелених зонах велику естетичну роль. Цю деревну породу культивують у садах і парках по всій Україні. У ландшафті дуже гарним є поєднання ялин колючих із зеленою, сріблястою, блакитною і сизою хвоєю [7].

Збір матеріалу проводили у вересні 2016 р. у штучних лісових насадженнях м. Дніпро. Моніторингова точка розташована на території, прилеглій до Придніпровської ТЕС, яка є найпотужнішим забруднювачем міста. Частка оксиду сульфуру (IV) в іiї викидах складає 90,0 \% від вмісту цієї сполуки у викидах усіх підприємств міста, оксиду нітрогену (IV) - 77,2 \%, твердих домішок $-75,7$ \%, оксиду карбону (II) - 68,8 \% [5]. Контрольна (умовно чиста) зона розміщена в Ботанічному саду ДНУ, де концентрації забруднювачів не перевищують ГДК [6].

Проби ялини колючої відбирали з модельних дерев одного вікового стану з гілок середнього ярусу південно-східного боку крони. В контрольній зоні було відібрано 60, на території проммайданчика - 30 однорічних пагонів, які відрізнялися порядком галуження: пагони подовження скелетних гілок і бічні пагони галуження (осі II та III порядку відповідно). Вимірювання біометричних показників пагонів проведено за загальноприйнятими методиками [4]. Коефіцієнт інтенсивності росту хвої розраховували за Т. О. Сухарєвою [10], коефіцієнт охвоєння - за методикою [3].

Повторність досліду була 30-60 вимірювань для кожного параметра пагона 3 кожної пробної ділянки. Результати експерименту оброблені статистично за допомогою програми Microsoft Office Excel 2007. Розраховували середню арифметичну похибку, для порівняння вибірок використовували t-критерій Стьюдента 3 попередньою оцінкою вибірки на нормальність.

Результати досліджень та їх обговорення. Як видно із табл. 1, річні прирости бічних пагонів ялини колючої під впливом антропогенного забруднення сут- 
тєво зменшуються: цей показник у пагонів подовження скелетних гілок складає 34,8 \% від довжини однорічного пагона рослин умовно чистої зони, а у пагонів галуження - 43,8 \%. Отже, величина пагонів галуження знижується меншою мірою, ніж пагонів подовження.

Табличя 1

\section{Вплив техногенних умов зростання на морфометричні показники однорічного пагона Picea pungens, $\mathrm{M} \pm \mathrm{m}$}

\begin{tabular}{|l|c|c|}
\hline \multicolumn{1}{|c|}{ Показник } & $\begin{array}{c}\text { Ботанічний сад ДНУ } \\
(\mathrm{n}=60)\end{array}$ & $\begin{array}{c}\text { Придніпровська ТЕС } \\
(\mathrm{n}=30)\end{array}$ \\
\hline Річний приріст бічного пагона, см: & $12,45 \pm 0,13$ & $4,33 \pm 0,80^{*}$ \\
- подовження скелетних гілок & $8,93 \pm 0,46$ & $3,91 \pm 0,21^{*}$ \\
- галуження & & \\
Кількість хвоїнок на модельній гілці,шт.: & $1563,75 \pm 75,37$ & $1974,83 \pm 162,54^{*}$ \\
- загальна & $1558,73 \pm 127,94$ & $1954,08 \pm 154,40^{*}$ \\
- живих хвоїнок & $5,92 \pm 1,75$ & $20,75 \pm 2,24^{*}$ \\
- усохлих хвоїнок & $0,048 \pm 0,001$ & $0,056 \pm 0,002^{*}$ \\
Коефіцієнт охвоєння пагона & \\
\hline
\end{tabular}

Примітка: * - дані достовірні при р <0,05.

Загальна кількість хвоїнок на модельній гілці значно перевищує контрольну величину (на 26,3\%). Основна частина голок як контрольних, так і дослідних ялин живі, асимілюючі, без пошкоджень, лише $0,4 \%$ хвоїнок у рослин чистої зони та 1,1% у рослин, що піддаються дії Придніпровської ТЕС, втрачають здатність до фотосинтезу і всихають (табл. 1). За даними П. В. Черних, А. Н. Єршової (2011) рівень некротичних уражень хвої ялини колючої (21-92 \%) варіював залежно від віку дерев і зон забруднення, тому автори пропонують використовувати показник появи некрозів у ялини колючої як якості індикатора стану навколишнього середовища у великих містах [11].

Коефіцієнт охвоєння ялини колючої, розрахований як співвідношення річної кількості хвої бічних пагонів до загальної їі маси, нижчий у контрольній зоні (табл. 1). В умовах техногенезу цей параметр зростає за рахунок утворення більшої кількості хвоїнок.

Довжина і маса хвоїнки досить чутливі до дії фітотоксикантів, оскільки їх значення в умовах техногенезу суттєво знижуються порівняно 3 контрольними величинами (рис. 1). У дослідних рослин ялини колючої довжина хвоїнки складає лише 64,6 \% від контрольного значення, а ії маса - 85,1%. Ширина хвоїнки за дії антропогенного навантаження практично не змінюється (відмінності між контрольними та дослідними значеннями цього показника недостовірні при $\mathrm{p}<0,05$ ). У зв'язку з цим збільшення охвоєння пагонів в умовах промислового забруднення може певною мірою компенсувати зменшення асиміляційної поверхні хвоїнок у досліджуваної деревної породи.

Наші дані узгоджуються 3 результатами досліджень інших науковців. Так, T. I. Великородько (2002) виявила, що у рослин сосни звичайної, які зростають в районі ТЕС (Донецька область), лінійні розміри хвої знижуються як порівняно 3 рослинами, що підпадають під вплив викидів СВО «Азот», так і з умовним контролем [3]. Т. О. Сухарєвою (2004) показано, що за умов промислового забруднення відношення маси хвоїнки до ії довжини - коефіцієнт росту хвої - є діагностичною ознакою стану рослин ялини сибірської, яку запропоновано використовувати для оцінювання життєвого стану хвойних порід [10]. Як показали наші дослідження, для ялини колючої цей показник не може бути інформативним тест-параметром стану рослин у техногенному середовищі, оскільки за дії забруднювальних речо- 
вин він майже не змінюється (відмінності між контрольним і дослідним значеннями показника недостовірні при $\mathrm{p}<0,05)$.

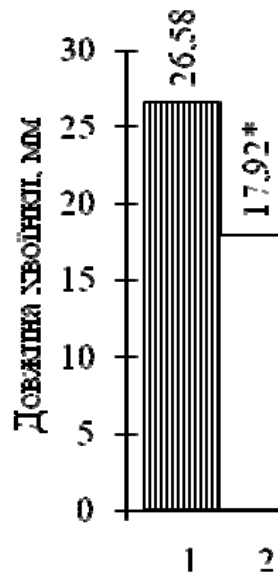

A

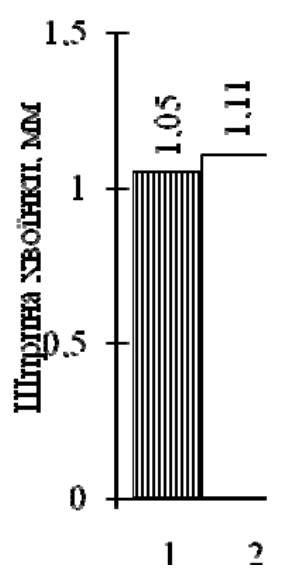

Б

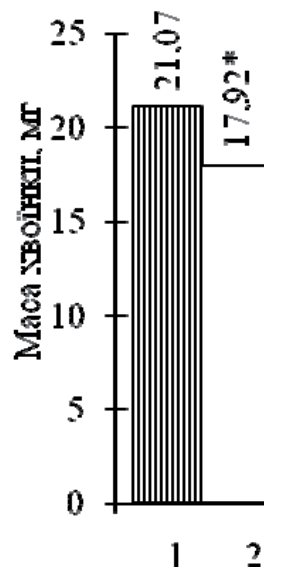

B

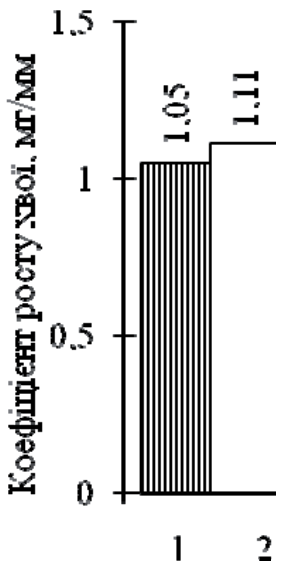

$\Gamma$

Рис. 1. Вплив техногенних умов зростання на морфометричні показники хвої ялини колючої (n=60), М \pm m: А - довжина хвоїнки, Б - ширина хвоїнки, В - маса хвоїнки,

Г - коефіціснт росту хвої. 1 - Ботанічний сад ДНУ, 2 - Придніпровська ТЕС

Примітка: * - дані достовірні при р <0,05.

Висновки. Вивчення морфометричних характеристик бічних пагонів ялини колючої показало, що в техногенних умовах зростання має місце пригнічення росту однорічних пагонів подовження та галуження, а також хвоїнок, що проявляється у зменшенні порівняно з контролем їх біометричних показників - довжини та маси. Це дає змогу використовувати ялину колючу з метою фітоіндикації стану рослин цього виду на техногенних територіях міста.

Підвищення кількості хвоїнок на модельній гілці й коефіцієнту охвоєння ми вважаємо адаптивними механізмами компенсаторного типу. Останні реакції-відповіді ялини колючої на антропогенний стрес забезпечують нормальний перебіг процесу фотоасиміляції та збереження життєздатності дерев цього виду в техногенних умовах зростання.

\section{Бібліографічні посилання}

1. Бессонова В. П. Моніторинг негативного впливу техногенних емісій на стан деревних рослин. Матер. I Всеукр. конф. «Теоретичні та прикладні аспекти соиіоекологї̈» (Львів, 7-11 жовтня 1996). Львів. 1996.

2. Бессонова В. П. Семенное возобновление древесных растений и промышленные поллютанты $\left(\mathrm{SO}_{2}\right.$ и $\left.\mathrm{NO}_{2}\right)$. Запорожье. 2001. 193 с.

3. Великородько T. I. Стійкість і мінливість сосни звичайної (Pinus sylvestris L.) в техногенно забруднених умовах південного сходу України: автореф. дис. на здобуття наук. ступеня канд. біол. наук: 03.00.16. Дніпропетровськ. 2002. 19 с.

4. Григора І. М., Якубенко Б. $\boldsymbol{C}$. Польовий практикум з ботаніки. Київ, 2005.

5. Екологічний паспорт Дніпропетровської області (2015р.). URL: http://www. menr.gov.ua

6. Смець М. А., Сердюк Я. Я. Оцінка стану території міста Дніпропетровська за ступенем забруднення атмосферного повітря. Екологія та природокористування. 2003. № 6. C. 200-207.

7. Зайцева I. O., Опанасенко В. Ф. Путівник по ботанічному саду ДНУ. Дніпропетровськ: РВВ ДНУ, 2008. 112 с. 
8. Коваль I. М. Динаміка радіального приросту і санітарного стану соснових деревостанів в умовах аеротехногенного забруднення в Поліссі та Степу: автореф. дис. ... канд. с.-г. наук: 06.03.03 Харьков: 2002. 18 с.

9. Приступа И., Романчук Т. Некоторые биоэкологические особенности представителей рода Juniperus L., произрастающих в условиях промышленного города. Bicнuк Київського націіонального ун-ту. Інтродукиія та збереження рослинного різноманіття. 2009. Вип. 27. С. 136-138.

10. Сухарева $\boldsymbol{T}$. $\boldsymbol{A}$. Химический состав и морфометрические характеристики хвои ели сибирской в условиях воздушного промышленного загрязнения: дис. ... канд. биол. наук: 03.00.16 / Апатиты, 2004. 228 с. РГБ ОД, 61:05-3/68.

11. Черных П. В., Ериова А. Н. Исследование морфологических отклонений ассимиляционных органов хвойных в условиях техногенного загрязнения. Воронежский гос. пед. ун-т. 2011.

12. Ярмишко В. T. Сосна обыкновенная и атмосферное загрязнение на Европейском Севере. СПб. 1997. 210 с.

Надійшла до редколегії 20.06.2017 p.

УДК 595.1+636.083.14

А. Е. Пахомов, А. А. Дубина, А. А. Рева, М. В. Шульман

Днепровский национальный университет имени Олеся Гончара

\section{ВОЗДЕЙСТВИЕ МЫШЕВИДНЫХ ГРЫЗУНОВ \\ НА ИНТЕНСИВНОСТЬ РАЗЛОЖЕНИЯ ПОДСТИЛКИ В ОСНОВНЫХ ЛЕСНЫХ БИОГЕОЦЕНОЗАХ ПРИСАМАРЬЯ}

Исследовано воздействие мышевидных грызунов на степень разложения подстилки в двух основных лесных биогеоенозах Присамарья. Установлено, что скорость разложения подстилки в летний период в липо-ясеневой дубраве под влиянием мышевидных грызунов увеличивается в 1,14 раза, а в сосновом бору на арене - в 1,21 раза. Ускорение разложения подстилки под влиянием мышевидных грызунов обусловлено двумя аспектами - поступлением экскреторного опада, являющегося мощным катализатором развития редуцентной микрофлоры, а также участием грызунов в механической мацерации опада и перемешивании подстилки с почвой.

Ключевые слова: мышевидные грызуны, лесная подстилка, экскреторный опад, фракционный анализ подстилки.

\section{О. С. Пахомов, А. О. Дубина, О. А. Рева, М. В. Шульман}

Дніпровський начіональний університет імені Олеся Гончара

\section{ВПЛИВ МИШОПОДІБНИХ ГРИЗУНІВ НА ІНТЕНСИВНІСТЬ РОЗКЛАДАННЯ ПІДСТИЛКИ В ОСНОВНИХ ЛІСОВИХ БІОГЕОЦЕНОЗАХ ПРИСАМАР'Я}

Досліджено вплив мишоподібних гризунів на ступінь розкладання підстилки у двох основних біогеоценозах Присамар'я. Встановлено, що швидкість розкладання підстилки в літній період у липово-ясеневій діброві під впливом мишоподібних гризунів збільшується в 1,14 раза, а в сосновому бору на арені - у 1,21 раза. Прискорення розкладання підстилки під впливом мишоподібних гризунів обумовлено двома аспектами - надходженням екскреторного опаду, який с потужним каталізатором розвитку редуцентної мікрофлори, а також участю гризунів у механічній мацерації опаду та перемішуванні підстилки з грунтом.

Ключові слова: мишоподібні гризуни, лісова підстилка, екскреторний опад, фракційний аналіз підстилки.

(C) А. Е. Пахомов, А. А. Дубина, А. А. Рева, М. В. Шульман, 2017 